\title{
Moving Toward Ecosystem Management: Examining a Change in Philosophy for Resource Management
}

\author{
Mary G. Wallace, Hanna J. Cortner, Margaret A. Moote, and Sabrina \\ Burke
}

\section{Introduction}

Today we are undergoing a fundamental shift in attitudes about natural resources and the environment from a focus on the production of commodities to a focus on the ecological condition of the land (H.Cortner and M.Moote 1994; J.Rowe 1992; Society of American Foresters 1992). Concern for commodity production is now augmented by increased concern for preservation and, in some cases, restoration of the natural landscape. Land is increasingly valued for reasons such as scenic beauty, alternative forest products, and wildlife habitat, as well as in its own right (P.Erlich and A.Erlich 1992; H.Rolston 1988). Goals of land management have broadened to include biodiversity and the maintenance and restoration of ecological processes (E.Grumbine 1994; G.Aplet, T. Olson, and V.A. Sample 1993). Further, there is growing awareness of the social context within which resource management takes place (R.Cawley and J.Freemuth 1993; B.Norton 1992).

Scientists, land managers, and others increasingly are proposing ecosystem management as the best way to manage our nation's resources. The major federal resource management agencies, including the USDA Forest Service, the National Park Service, the Bureau of Land Management, the U.S. Fish and Wildlife Service, and the Natural Resources Conservation Service (formerly the Soil Conservation Service) as well as the Executive Office of the White House, have all officially adopted ecosystem management (Interagency Ecosystem Management Task Force 1995; W.Morrissey, J. Zinn, and L. Corn 1994; FEMAT 1993). As currently proposed, ecosystem management takes an holistic view of the natural world. Generally, the sustained yield of products is considered within the context of the sustainability of the entire ecosystem (J.Franklin 1993). A primary goal of ecosystem management is to maintain healthy ecological conditions to ensure species, plant, and ecosystem viability (D.Iverson 1993a). Yet, it is a management philosophy that depends as much on understanding political and social factors as it does on understanding biological information (W.Shands, A. Black, and J. Giltmier 1993). Further, ecosystem management calls for a shift in the way humans approach the natural world; it requires an explicit examination of the relationship between humans and nature, our patterns of politics, and methods of scientific inquiry. 
In the past, discussions about our attitudes toward natural resources have been framed largely by opposing the philosophies of John Muir against those of Gifford Pinchot--a preservationist view against a utilitarian perspective. ${ }^{1}$ Natural resource policy in the United States in particular is often viewed along this continuum, but the roots of this discussion about the relationship between humans and nature run much deeper and are found in the wider context of Western political thought. Further, and also rarely recognized in modern debates, definition of the relationship between humans and the natural world has important implications beyond whether nature is to be preserved or utilized. Specifically, the way in which a society defines this relationship is reflected in theoretical principles concerning governance, methods of scientific inquiry, and interactions among humans, as well as in natural resource policies (R.Cawley and J.Freemuth 1993; E.Bird 1987; W.Leiss 1974). The overly simplistic Muir-Pinchot dichotomy needs to be reexamined to link natural resource policy in the American experience to a larger theoretical and historical context.

If we are indeed moving toward ecosystem management as a new philosophy to guide resource management, we must explore how this approach differs from the theoretical assumptions of current natural resource management. The intent of this paper is to use critical theory to examine the theoretical underpinnings of resource management in the Western United States, which have been particularly influenced by the political thought prevalent during the era of Enlightenment. In the first section we briefly discuss the relationship between theory and practice and argue that critical theory is well suited to explore both this nexus and environmental issues. We then examine Enlightenment thought and critical theory's critique of it along four dimensions: the relationship between humans and nature, the concept of rationality, the role and structure of science, and social relations among humans. After then examining how Enlightenment thought has significantly influenced natural resource management in the West, the paper illustrates how ecosystem management addresses the critical theorists' arguments by offering alternative theoretical principles to undergird a new resource management philosophy. These include a new relationship between humans and the natural world, an expanded sense of reason, a more integrated and holistic science, and institutional changes that disperse power and authority more widely among the citizenry. The paper concludes with a review of recent natural resource management efforts that reflect ecosystem management themes in practice.

\section{Political Theory and Public Policy}

Political theorists and public policy scholars often stand at opposite ends in political science -- rarely do researchers from either field engage in a common discourse. As Stone observes, "the study of public policy, as it is conveyed in much of the political science literature, is remarkably devoid of theory." 2 Political scientists have offered "an unexciting and unpersuasive 'production' model of policy, whereby policy is assembled in stages, as

1. Cawley and Freemuth (1993) call these perspectives the "Mother Earth script" and the "Tree Farm script."

2. D. Stone (1988) Policy, Paradox and Political Reason p.vii. Notable exceptions include: J. Rodman, (1980) Paradigm Change in Political Science: An Ecological Perspective; J. Dryzek, J. (1990a) Discursive Democracy; and M. Sandel, (1988) The Political Theory of the Procedural Republic. 
if on a conveyor belt" (D.Stone 1988:vii-viii). Far too often the link between political theory and the development of policy options is ignored, although there is much to be gained in moving from the level of practice (policy) to examining theoretical principles and linking the two. Political theories underlie every public policy (P.Stillman 1974). Examining the principles underlying various approaches to natural resource management shows that each yields much different answers to important questions about natural resource policy and governance in general: What is the view of our society toward nature? What is the role of government in the management of natural resources? What is the role of the market? What is the role of citizens in forming natural resource policy? Answers to questions such as these form the basis upon which natural resource policies are made. The analysis of these theoretical principles can improve our understanding of current problems and can be used to develop criteria to evaluate policies and to frame new theories and policy alternatives.

Although traditionally policy and theory have been approached separately, there is increasing recognition that decisions concerning public policies do reflect larger theoretical principles (R.Goodin 1982). For example, the analysis of political theory "can define and illuminate alternatives and can provide a comprehensive framework from which policy decisions can be made and judged" (P.Stillman 1974:50). Reich, for example, calls the set of assumptions underlying policy decisions "the philosophy of policy making." As he explains:

Beneath the daily activities of elected officials, administrators, and their advisors and critics, and beneath the public's tacit decision to accord legitimacy to specific policy decisions, exist a set of first principles that suggest what good policy-making is all about. They comprise a view of human nature, of how people behave as citizens. They also reflect a view of social improvement, of why we think that society is better in one state than another. And they offer a view of the appropriate role of government in society -- given human nature, our aspirations of social improvements, and our means of defining and solving public problems (R.Reich 1988:1).

Key theoretical principles, implicit and explicit, are embodied in our practices and institutions and underlie every natural resource policy. These principles contain assumptions about what makes a good society and good government.

Seeking the nexus between theory and practice is an important premise underlying this paper. As MacIntyre (1984:61) observes,

there ought not to be two histories, one of political and moral action, and one of political and moral theorizing, because there were not two pasts, one populated only by actions, the other only by theories. Every action is the bearer and expression of more or less theory-laden beliefs and concepts; every piece of theorizing and every expression of belief is a political and moral action.

Sandel similarly reminds us that "our practices and institutions are embodiments of theory," and that "for all our uncertainties about ultimate questions of political philosophy -- of justice and the nature of the good life -- the one thing we know is that we live some answer all the time" (M.Sandel 1988:81, emphasis in original). Thus, policy and theory 
are inextricably linked. From this perspective, policy is not solely an autonomous subject of study, but also a subfield of political theory (M.Sandel 1988:109).

Most significantly, it is in the nexus between theory and practice that changes in society can be forged. In Lukacs' words, "when theory and practice are united it becomes possible to change reality" (G.Lukacs 1971:189). Practice shapes theory and theory shapes practice. Understanding the connections between the practical and the theoretical is key to undertaking any issues involving social change. Social change can result from the "reciprocal interplay of idea and reality, theory and practice" (W.Leiss 1974:176).

\section{Critical Theory}

Forging linkages between theory and practice is a primary focus of the school of political theory called critical theory; it seeks to reunite theory and practice by linking theoretical questions to practice through a critical and emancipatory lens (S.Leonard 1991; D.Kellner 1989; J.O'Neill 1976). A key thrust of critical theory is that it strives "not always successfully -- to overcome the division between theory and practice" (D.Kellner 1989:8). As Forester (1985:xvi) argues, critical theory seeks "to illuminate the intersection of action, structure, and possibility, that intersection where pragmatics and vision may flourish together." Moreover, unlike mainstream political science, critical theory is often directly tied to political issues and political action, particularly by those opposed to racism and those interested in ecological issues (P.Wexler 1991:vii). Specifically, critical theory has been suggested as a way to understand and improve the relationship between humans and the natural world (J.Whitebrook 1979; V.Di Norcia 1974; W.Leiss 1974).

In recent years, there has been a resurgence of interest in applying critical theory to a wide range of social problems precisely because of its aim to integrate political theory and political practice (S.Leonard 1991; P.Wexler 1991). ${ }^{3}$ As Leonard (1991:3) contends, however, forging this link between theory and political practice is no small task: "Today it is commonly understood that theory may explain social processes, but it is nevertheless quite independent of political practice." The challenge to critical theory is to present new syntheses of philosophy, social theory, cultural critique, and radical politics (D.Kellner 1989:233). Kellner (1989:1), for example, argues that critical theory is most effective when it is "informed by multidisciplinary research, combined with the attempt to construct a systematic, comprehensive social theory that can confront key social and political problems of the day." Similarly, Leonard (1991:4) offers guidelines for critical theory, arguing it must "inform an emancipatory political practice: it must locate the sources of domination in actual social practices; it must project an alternative vision (or at least the outline) of a life free from such domination; and it must craft these tasks in the idiom, so to speak, of which it addresses." In sum, critical theory is an ideal vehicle through which to explore questions concerning environmental issues; it not only offers a method to critique the past but, also, it is hoped, outlines paths for future action.

3. In the past, critical theory has been criticized on the grounds that it is simply critical and does not illuminate paths for future action, and that it has moved too far from its original mission to link theory and practice to address social inequities and ills. 


\title{
Enlightenment Thought
}

Critical theory provides a unique lens through which to view the Enlightenment era and its influences on modern society. Enlightenment thought emerged during the seventeenth and eighteenth centuries and includes a large and diverse body of literature including the writings of Descartes, Kant, Hegel, Locke, and Hume. Enlightenment thought encompasses several generations with branches in various European countries and North American countries (P.Gay 1969). Theorists, even those who rarely agree, concede that Enlightenment thought has had a profound effect on the Western world, particularly in the United States (H.Commager 1977).

The Enlightenment marked a new era for human civilization. Principles of Enlightenment thought largely shape how we view the modern world; they continue to influence writers and thinkers today, the form of societal structures, and the conduct of scientific inquiry. Enlightenment writers are a diverse lot. ${ }^{4}$ As Connolly (1988: 107) notes:

\begin{abstract}
The Enlightenment, of course, is divided into camps. Some parties give primacy to rights and others to utility; some think they can support a correspondence theory of truth and others adopt a more pragmatic theory; some think there is no God and others think that a God with a limited earthly presence is necessary to the integrity of reason, morality and politics; some incline toward the market and others toward the state; some favor democracy and others a bureaucratic politics; some celebrate individual freedom and others believe that freedom can exist only in community.
\end{abstract}

Although profound differences exist among these writers, as a whole they share similar beliefs in the power of reason, the rejection of superstition and authority, the supremacy of the individual, and a firm belief in human progress.

Part of the allure of Enlightenment thought has always been its promises. For example, Enlightenment thought views knowledge as a liberating force to help move people toward human liberty, equality, and progress. In contrast to medieval times, as Gay (1969:5) observes:

In the century of Enlightenment, educated Europeans awoke to a new sense of life. They experienced an expansive sense of power over nature and themselves: the pitiless cycles of epidemics, famines, risky life and early death, devastating war and uneasy peace -- the treadmill of human existence -- seemed to be yielding at last to the application of critical intelligence.

To achieve this liberation, Enlightenment thought sought to intensify the "light of reason, first lit in Greece, which had been 'rekindled' in the fourteenth century after almost a millennium of darkness" (P.Hulme and L.Jordanova 1990:1). The promises of the Enlightenment include the "triumph of reason over superstition, as subjecting supposed authorities to reasoned criticism, as a movement toward human liberty and equality,

4. Lutz (1992:127) divides Enlightenment thought into four categories including antireligious, a natural religion strain that emphasizes reason, a moderate liberal view, and an empirically based view. 
knowledge and progress. In this golden picture reason and science are the progenitors, and justice, peace, and democracy the children of the Enlightenment" (O.O'Neill 1990:186).

Enlightenment thought is anchored on the concept of reason. Reason is seen as a way to escape the strictures of society. Kant (1990:83) provides a succinct definition:

Enlightenment is man's release from his self-incurred tutelage. Tutelage is man's inability to make use of his understanding without direction from another. Selfincurred is this tutelage when its cause lies not in lack of reason but in lack of resolution and courage to use it without direction from another. Sapere aude! (Dare to be wise.) Have courage to use your own reason - that is the motto of enlightenment.

As Kant further notes, Enlightenment thought is centered on the individual. In contrast, in the Greek world, the social and political community, and political institutions in particular, were considered essential in helping form good citizens. ${ }^{5}$ Enlightenment thought, on the other hand, "expresses vociferously the principle of individuality; it insists that individual reason, or individual conscience or individual feeling must be given priority both in the life of self and in the life of the whole" (W.Connolly 1988:100). As Kant so concisely notes, "the maxim of always to think for oneself is enlightenment" (as cited in O.O’Neill 1990:195).

For Enlightenment writers, the individual, armed with reason, could stand against any authority -- whether it be the church or the monarchy (L.Jordanova 1990). As Hawthorn observes, the Enlightenment meant that "there was no longer the need to rely upon persons and institutions who claimed privileged access to the good. It was now accessible to all men by virtue of the uniquely and universal human faculties of reason and experience" (G.Hawthorn 1976:13). This promise held out the hope of loosening the societal strictures present in the seventeenth and eighteenth centuries. A strong belief in progress also characterized this period: through the pursuit of truth and knowledge, humans would realize progress in the social world.

Without doubt, much of the progress we enjoy today in social equality and in the quality of political life was initiated by Enlightenment thought. For example, the rejection of dogma and superstition and the arbitrary use of authority are enduring contributions to Western political systems. Also, the principles of political equality and individual rights -principles embodied in the U.S. Constitution -- are largely the heritage of this era. The power of science and technology to improve our lives also cannot be denied.

\section{The Dark Side of Enlightenment}

Despite its contributions, the Enlightenment era failed to bear fruit to many of its promises. Burke, Hegel, Goethe, Shelly, and Nietzsche were all early critics of the Enlightenment (O. O'Neill 1990). ${ }^{6}$ These authors, as well as others, saw a darker side to the Enlightenment, a more somber picture, one summed up by O'Neill (1990:186):

5. For Aristotle, in a view that has influenced theorists through time, man is a political animal, one who needs the polis (the Greek word for a city-state) to achieve full eudaimonia, the Greek word for happiness, a word that connotes a rich happiness, found by living a good life. 
It portrays the very ideals of the Enlightenment as symptoms of spurious rationalism and heedless anthropocentrism, and as heralds of a Godless and disenchanted world where only subjective values are left, and which is ruled by modes of social domination more complete and intrusive than those of the old despotisms. In this dark picture, the triumph of reason and science has destroyed not only religion but morality, not only tradition but human bonds. The legacy of the Enlightenment is a world of isolated and alienated individuals who find to their horror that nihilism, terror, domination, and the destruction of the natural world are the true offspring of the Enlightenment.

This darker side of the Enlightenment age was explored by the critical theorists associated with the Frankfurt school -- Horkheimer, Adorno, and later, Marcuse. ${ }^{7}$ Influenced in part by Marx, these early critical theorists carried the same spirit of critique Marx used toward political economy, but instead focused on culture, science, and particularly the concept of reason. ${ }^{8}$ Writing from the 1930s through the 1960s, and strongly influenced by the horrors of Nazi Germany and the Nazi's misuse of Enlightenment ideas, these writers began to question basic tenets of Enlightenment thinking. A central argument of these writers is that the very ideals of the Enlightenment - reason and science -- have at times been destructive. For these theorists, the culmination of Enlightenment thought can most clearly be seen in the relationship between humans and nature in contemporary society. In particular, they argue that humans have sought to dominate and master nature, and that this definition of the human-nature relationship has negatively shaped social relations and the formation and conduct of scientific inquiry.

In the "Dialectic of Enlightenment," for example, Horkheimer and Adorno (1993) define the aim of the Enlightenment as liberating humans from fear and thereby establishing their sovereignty over the natural world. As they contend, "the program of the

6. Rousseau's discussions on the inequalities imposed upon humans by society in his "Discourse on the Origin of Inequality" and the limitations of science in the "Discourse on Science and Arts" may also be considered early critiques of Enlightenment thought. 7. Critical theory is a product of the Institute for Social Research, which Kellner (1989) calls the first Marxist-oriented research institute in Germany. This institute is commonly referred to as the Frankfurt School. The critical theorists discussed in this paper include Horkheimer and Adorno, writing in the 1940s and 1950s, and Marcuse, writing in the 1950s and 1960s. This paper also includes writings from Habermas, who although also a critical theorist, writes from a much different perspective than the early Frankfurt theorists.

8. Marx is considered the "founding father" of critical theory. Although many are familiar with his ideas concerning communism, few realize that Marx began his writings with a commitment to critique of society. In his essay entitled "For a Ruthless Criticism of Everything Existing," he offers a new sense of spirit for political theory. As he notes, "we do not attempt dogmatically to prefigure the future, but want to find the new world only through criticism of the old. Up to now the philosophers had the solution of all riddles lying in their lectern, and the stupid uninitiated world had only to open its jaws to let the roast partridges of absolute science fly into its mouth... I am speaking of a ruthless criticism of everything existing, ruthless in two senses: The criticism must not be afraid of its own conclusions, nor of conflict with the powers that be" (K.Marx 1978:13). 
Enlightenment was the disenchantment of the world; the dissolution of myths and the substitution of knowledge for fancy" (M.Horkheimer and T.Adorno 1993:3). They argue that the promised liberation by Enlightenment thought has largely been a myth. Instead of liberation, they see a world filled with social domination -- the domination of humans over humans through the use of power, authority, and also scientific inquiry. To these theorists, Enlightenment thought has paradoxically caused a decline in social freedom. As they note: "We are wholly convinced -- and therein lies our petitio principii -- that social freedom is inseparable from enlightenment thought... The point is rather that the Enlightenment must consider itself, if men are not to be wholly betrayed" (M.Horkheimer and T.Adorno 1993:xiii; xv, emphasis in original). They sought to understand "why mankind, instead of entering into a truly human condition, is sinking into a new kind of barbarism" (M.Horkheimer and T.Adorno 1993:xi). ${ }^{9}$ The early critical theorists see four profound negative interrelated effects of Enlightenment thought on modern society, including an emphasis on human mastery over nature, a narrow conception of reason, science defined as positivism, and domination in the social world.

\section{The Domination of Nature}

Horkheimer and Adorno (1993:248) argue that the attitude of humans toward nature in modern society is one of "acquiring absolute mastery over nature, of converting the cosmos into one immense hunting-ground." Knowledge, especially in relation to the natural world, becomes a tool of domination. ${ }^{10}$ They argue that Francis Bacon had a profound influence on the development of science, especially in the way the Western world relates to nature. Horkheimer and Adorno characterize the relationship that Bacon draws between knowledge and nature as patriarchal, as one of mastery and domination over nature, and argue that this is how modern society approaches nature. Nature itself

9. Some scholars (Lenhardt 1976) argue that Horkheimer and Adorno's arguments in this book were largely personal and shaped by their horror of the rise of fascism in Germany. However, Rocco persuasively argues that this book is an attempt, and a masterful one at that, "to juxtapose an image of the past to our vision of civilized modernity in a way that would open up the present to critical assessment" (C. Rocco 1994:77).

10. An alternate theory of the source of man's domination over nature is offered by White (1967:28), who argues the source of domination over nature is the Judeo-Christian religion. White argues, in essence, that "to a Christian a tree can be no more than a physical fact." This argument has been largely debunked by Moncrief (1973) who argues that cultural factors are much more important, and Dubos (1973), who argues that White erred on theological grounds. Steffen (1992) also contends that White erred in his interpretation of Genesis and offers another interpretation that bases the human and nature relationship in Genesis on an ideal of human-divine intimacy and peacefulness. For example, an alternative to White's conception of a Christian attitude toward nature is found in the writings of St. John of the Cross: "The mountains soar aloft; they are abundant, spacious, lovely to look upon, graceful, fragrant with flowers. These mountains my Beloved is to me...The solitary valleys are peaceful, pleasant, cool, shady, watered by running streams. In the diversity of their trees, in the joyous song of the birds, they refresh and delight the senses. In their solitude and silence they give rest. These valleys my Beloved is to me" (St. John of the Cross, S.C. XIII, as cited in E.Hamilton 1976:94). 
becomes an instrument because "what men want to learn from nature is how to use it in order wholly to dominate it and other men. That is the only aim.... Nature must no longer be influenced by approximation, but mastered by labor" (M.Horkheimer and T.Adorno 1993:19).

Marcuse (1966:104) later observed a similar relationship, contending that humans view "the world in terms of calculable, predictable relationships" in which "universal quantifiability is a prerequisite for the domination of nature." He argues for a different relationship with nature, contending that "cultivation of the soil is qualitatively different from destruction of the soil, extraction of natural resources from wasteful exploitation, clearing of forests from wholesale deforestation." He notes the emergence of small protected areas such as parks and gardens, but ultimately argues that "outside these small, protected areas, [society] has treated Nature as it has treated man -- as an instrument of destructive productivity" (H.Marcuse 1966:240).

\section{Instrumental Rationality}

A second criticism of the Enlightenment era by these critical theorists is that the concept of reason changed and took on a very narrow character. By comparison, Greek philosophers such as Aristotle had a much richer connotation of reason: It was a companion to wisdom and an integral part of the way to achieve true happiness. Horkheimer and Adorno, however, argue that during the Enlightenment era, the concept of reason changed substantially and was reduced to a mere instrument in social life. Similar to knowledge, reason, instead of being a tool of liberation, became an instrument for domination. Reason was reduced to a narrow conception of rationality -- instrumental rationality. It is this type of rationality, they argue, that underlies much of modern society. Instrumental rationality is defined as "the selection of efficacious means to previously given ends... that form of rationality which seeks to discriminate among alternative actions by assessing their comparative tendency to advance or to retard the achievement of the actor's goals or values" (L.Tribe 1973:618). Under instrumental rationality, the primary concern is the most efficient means for reaching a given end.

In "The Eclipse of Reason," Horkheimer (1947:3) further argues that reason has become focused only on means, with little importance attached to larger questions of whether the ends themselves are reasonable. He notes the decline of reason in modern life: "Reason as an organ for perceiving the true nature of reality and determining the guiding principles of our lives has come to be regarded as obsolete.... Reason has liquidated itself as an agency of ethical, moral, and religious insight" (M.Horkheimer 1947:18). This narrow form of reason, now divorced from objective content, becomes an instrument for domination: "Having given up autonomy, reason has become an instrument... reason has become completely harnessed to the social process. Its operational value, its role in the domination of men and nature, has been made the sole criterion" (M.Horkheimer 1947:21).

The consequences of this narrow type of reason for society are that concepts such as justice and equality lose their intellectual roots. There is no way to link them to any objective reality (M.Horkhemier 1947:23). The consequences for nature are that it "is today more than ever conceived as a mere tool of man. It is the object of total exploitation that has no aim set by reason, and therefore no limit" (M. Horkheimer 1947:108). Marcuse adds to this argument by offering a new element -- the influence of the technology. In OneDimensional Man, Marcuse focuses on the influences of modern technology on society. 
He argues that humans have become one-dimensional in advanced industrial technological societies, concerned solely with the most efficient means to rarely questioned ends. Under this view, technology is not a neutral force, but a totalitarian entity because we must all conform to its single dimension." In this one-dimensional society, Marcuse contends that the relationship between what is rational and what is irrational has been altered, especially in the political arena. For Marcuse (1966:ix, xiii), the technological society forms the political society and "this society is irrational as a whole... its sweeping rationality, which propels efficiency and growth, is itself irrational," precisely because larger questions concerning our attitudes toward efficiency and growth are rarely asked.

Marcuse further contends that the one-dimensional, technological age has supplemented instrumental rationality with technological rationality (H.Marcuse 1966:xvi). In contrast, reason is seen by Marcuse as a way "to promote the art of life... to live; to live well; to live better" (as cited in J.Whitebrook 1979:228). Marcuse argues that because the concept of reason has been reduced to one of technological rationality, "the historical function of reason has also been to repress and even destroy the urge to live, to live well, and to live better" (as cited in J. Whitebrook 1979:228). Technological rationality, justified on "rational" terms, also leads to a total domination of nature: "For man's struggle with Nature is increasingly a struggle with his society, whose powers over the individual become more 'rational' and therefore more necessary than ever before" $(\mathrm{H}$. Marcuse 1966:241).

\section{Modern Science}

The critical theorists argue that Enlightenment thought, with its emphasis on instrumental and technological rationality and the domination of nature has profoundly influenced scientific inquiry. Modern science has essentially become the handmaiden for the mastery of nature. The critical theorists note that the type of knowledge that the "Enlightenment has in mind is the form of knowledge which copes most proficiently with the facts and supports the individual most effectively in the mastery of nature" (M.Horkheimer and T.Adorno 1993:82-83, emphasis added). Other forms of knowledge that do not conform, such as folk knowledge or oral histories, are excluded -- "For the Enlightenment, whatever does not conform to the rule of computation and utility is suspect" (M.Horkheimer and T.Adorno 1993:6). The quantitative has replaced the qualitative.

The type of science thus produced is essentially positivism. ${ }^{11}$ Knowledge that can be quantified, verified by empirical methods, and reduced to unified laws, is prized. This conception of science has had profound impacts on language and culture as well. As Horkheimer and Adorno (1993:164) note, "the blindness and dumbness of the data to which positivism reduces the world pass over into language itself, which restricts itself to recording those data. Terms themselves become impenetrable."

For Marcuse, the narrowing of reason in the one-dimensional society described earlier has also affected the scope and conduct of scientific inquiry. In a one-dimensional

11. Webster's dictionary (1974:918) defines positivism as "a theory that theology and metaphysics are earlier and imperfect modes of knowledge and that positive knowledge is based on natural phenomena and their properties and relations as verified by the empirical sciences." 
technological society, "the science of nature develops under the technological a priori which projects nature as potential instrumentality, stuff of control and organization. And the apprehension of nature as (hypothetical) instrumentality precedes the development of all particular technical organization" (H.Marcuse 1966:153, emphasis in original). As he further explains:

\begin{abstract}
The quantification of nature, which led to its explication in terms of mathematical structures, separated reality from all inherent ends and consequently, separated the true from the good, science from ethics. No matter how science may now define the objectivity of nature and the interrelations among its parts, it cannot scientifically conceive it in terms of 'final causes'... science, by virtue of its own method and concepts, has projected and promoted a universe in which the domination of nature has remained linked to the domination of man -- a link which tends to be fatal to this universe as a whole (H.Marcuse 1966:166, 147, emphasis in original).
\end{abstract}

Marcuse argues nature must be viewed in more than instrumental terms to alleviate domination in the social world and that modern science also reflects an artificial split between the social and scientific worlds.

Werner Heisenberg similarly observes,

At the same time the human attitude toward nature changed from a contemplative one to the pragmatic one. One was not so much interested in nature as it is; one rather asked what one could do with it. Therefore, natural science turned into technical science; every advancement of knowledge was connected with the question as to what practical use could be derived from it (as cited in W.Leiss 1974:87).

This emphasis in science soon characterized the social sciences, as "the methodology of natural science became the model for arriving at objective judgments of any kind, and whatever could not meet this test was confined to the realm of the merely subjectiverelative" (W.Leiss 1974:134).

\title{
Domination of Humans over Humans
}

In their most controversial thesis, the Frankfurt theorists also contend that treating nature as an object of domination, reducing reason to instrumental rationality, and limiting science to that which can be quantified, ultimately leads to domination in the social world -- of humans over humans, and ultimately even of humans over themselves. They argue that the "rational" domination of nature causes humans to renounce other aspects of their being, including an appreciation of instincts, aesthetics, and other expressive parts of being human. Horkheimer and Adorno contend that in modern society there has been a "denial of nature in man for the sake of domination over non-human nature and over other men." This mastery of nature "is paid for in self-repression and the repression of others" (as cited in C.Rocco 1994:76, 77).

The repression of others is embedded in societal institutions and influences how humans treat each other and regard themselves. Horkheimer (1947:94) explains this thesis: 
The human being, in the process of his emancipation, shares the fate of his world. Domination of nature involves domination of man. Each subject not only has to take part in the subjugation of external nature, human and nonhuman, but in order to do so must subjugate nature in himself. Domination becomes 'internalized' for domination's sake. What is usually indicated as a goal -- the happiness of the individual, health, wealth -- gains its significance exclusively from its functional potentiality.

As a result, "the individual is wholly devalued in relations to the economic powers, which at the same time press the control of society over nature to hitherto unsuspected heights" (M. Horkheimer and T.Adorno 1993:xiv).

Marcuse also argues that in this technological age there is a link between social control, economic issues and technology. For Marcuse (1966:146), in modern society:

The struggle for existence and the exploitation of man and nature became ever more scientific and rational.... Scientific management and scientific division of labor vastly increased the productivity of the economic, political, and cultural enterprise. Result: the higher standard of living. At the same time and on the same ground, this rational enterprise produced a pattern of mind and behavior which justified and even absolved even the most destructive features of the enterprise. Scientific-technical rationality and manipulation are welded into new forms of social control.

He contends that, in the name of progress, technical rationality is linked to social control as well as control of nature, and that domination in the social world is also embedded in methods of scientific inquiry.

\section{Implications}

In sum, the critical theorists provide an insightful examination of the influence of Enlightenment thought on modern society. More importantly, though, they offer a useful framework through which to view ecological issues. These theorists argue that knowledge, conceived of as a liberating force by Enlightenment thought, has often been used instead as a tool to dominate nature and as a way for humans to dominate humans. They argue that the mastery of nature is accomplished through instrumental rationality and embedded in society's institutions. Further, they contend that the domination of nature leads to the domination of humans over humans and ultimately over one's own inner self. Finally, positivism not only served as a tool for the mastery of nature, but also limited the nature of scientific inquiry to preconceived categories and principles.

In the critique offered by the critical theorists lie directions for addressing the tensions currently present concerning ecological issues in the modern world. Their writings suggest that solutions to our current environmental problems may be found in a new relationship with nature, an expanded sense of reason that focuses on ends, not just means, a more holistic conception of science, and more equality in social relations.

As Horkheimer (1992:127) concludes: 
In summary, we are the heirs, for better or worse, of the Enlightenment and technological progress. To oppose these by regressing to more primitive stages does not alleviate the permanent crisis they have brought about. On the contrary, such expedients lead from historically reasonable to utterly barbaric forms of social domination. The sole way of assisting nature is to unshackle its seeming opposite, independent thought.

Only by unmasking sources of domination can the liberation of knowledge through independent thought be possible, and this unmasking must begin with our attitudes toward the natural world. As a modern theorist who has been influenced, in part, by these critical thinkers, notes: "nature was not simply disenchanted by the Enlightenment--it was killed" (J.Dryzek 1990b:198).

\section{Enlightenment Thought and the American Experience}

American culture and society has been strongly influenced and defined by Enlightenment thought. As Henry Steele Commager (1977:xii) notes:

The Old World imagined, invented, and formulated the Enlightenment, the New World... realized it and fulfilled it. It was the Americans who not only embraced the body of Enlightenment principles, but wrote them into law, crystallized them into institutions and put them to work. That, as much as the independence and the creation of the nation, was the American Revolution (emphasis in original). ${ }^{12}$

Enlightenment thought, reflected in the writings of Locke (L.Hartz 1955), Montesquieu and Hume (D.Lutz 1992), is also cited as one of the more significant influences on the Declaration of Independence and the U.S. Constitution.

The influence of Enlightenment thought can most clearly be seen in U.S. Western resource policy (J.Curry-Roper and S.McGuire 1993; W.Ophuls 1974; D.Orr and S. Hill 1978). The Western frontier, with its seemingly unlimited resources and freedom from societal strictures, was a perfect testing ground for Enlightenment thought. From water to range lands to forest lands, most policies governing resource allocation and management in the Western United States reflect the attitudes toward nature, reason, and science described earlier by the critical theorists (D.Worster 1992). ${ }^{13}$ Further, most natural resource policies traditionally have emphasized the ascendancy of the rational individual, often defined solely through economic terms, over the community as a whole (J.CurryRoper and S.McGuire 1993). "All too often, for reasons that should not surprise us, it is to the language of economics that administrators turn in order to talk 'rationally' about the interdependence of the choices they face" (R.Bellah et al. 1992:115) ${ }^{14}$ The western

12. Other influences on the founding fathers that have been suggested include forms of English and Classical Republicanism, Medieval thought, the governance structures of the Iroquois Indians, and economic and class factors present at the time (see D.Lutz 1992).

13. Policy analysis also generally reflects the themes of instrumental rationality and of a positive reductionist science. See Dryzek (1990a) and Stone (1988) for discussions of the implications of these themes for policy analysis. 
frontier was transformed by the desire to master nature, a narrow utilitarian conception of reason, and science rooted in positivism.

\section{Western Resource Management}

Overall, the underlying goal driving many past and current resource management efforts in the American West has been the domination and mastery of nature (M.Reisner 1986; W.Stegner 1987; D.Worster 1992). As Wallace Stegner notes, the building of society in the U.S. West required "the maximum domination of nature" (W.Stegner 1987:55). The arid nature of the West left settlers with two options -- "either adapt to it or try to engineer it out of existence" (W.Stegner 1987:27). For much of the last century, the latter option -- to engineer aridity out of existence -- has been chosen.

This attitude and spirit is clearly reflected in the fate of Western river basins in the United States. For instance, from the turn of the century until today, it has been the drive to master nature that:

has so damned, diverted, used, and reused the Colorado River that its saline waters now never reach the Gulf of California, but die in sand miles from the sea; that has set the Columbia, a far mightier river, to tamely turning turbines; that has reduced the Missouri, the greatest River on the continent, to a string of ponds; that has recklessly pumped down the water table of every western valley (W.Stegner 1987:46).

In the words of the Bureau of Reclamation, the agency turned "a natural menace" -the Colorado River -- into a "natural resource... to be utilized to the very drop" (M.Straus 1946). Worster also discusses this desire to master the Western landscape and describes the West as a "hydraulic society" (Worster 1992). He borrows the term from Wittfogel, also a critical theorist, who coined it to describe the rise and ultimately subsequent failure of large advanced irrigation societies throughout history. Worster contends that the Western United States is the largest hydraulic society ever built.

Worster also comments on the domination of humans over humans in resource allocation and management. He contends the American West is "ruled by concentrated power, though here, as in other places, power has often hidden behind beguiling masks" (D. Worster 1992:15). This observation is ironic. Historically, a powerful myth exalting the ideal of rugged individualism permeated attitudes about the American West. Myths, images, and symbols have long been the stuff the West is made of. ${ }^{15}$ Instead, the American West is an area that has required massive infusions of federal monies (C.Wilkinson 1992).

There is another myth of the region as having "a large, spacious, independent, sunburned self-reliant character, and a large open, democratic western society" (W.Stegner 1987:17). In many parts of the American West, however, the process by which decisions about resource allocation and use are made is best defined not as a democracy, but as a plutocracy -- government by the wealthy -- and as an oligarchy -- government by the few.

14. Bellah et al. (1992:117) report the following: "An economist at the Environmental Protection Agency, when asked, 'What about the theory that human life is priceless?' answered, we have no data to support that."' 
As Stegner observes, "It would take fast footwork to dance the society based on big reclamation projects into a democracy. Even the cattle kingdom from which we derive our most individualistic and independent folk hero was never a democracy as the Middle West, say, was a democracy" (W.Stegner 1987:69). ${ }^{16}$ Inequalities in natural resource policy are common, with a few groups receiving most of the benefits, while others, such as Indian tribes, historically were shut out from the use of natural resources, particularly water (F.L.Brown and I.Ingram 1987). As Leiss observes, "the legend of the equality of rights and individual freedom, however, together with the illusion of popular choice under the conditions of mass democracy, still veil the reality in which the decisions of the few govern the lives of the many" (W.Leiss 1974:169).

Whether discussing water, grazing, or forestry, the same themes resonate in western resource use. Natural resources are often controlled by the few, for the profit of a few, and largely at the expense of the federal taxpayer. Government policies have placed control of the region's natural resources in the hands of corporations, not the rugged individual farmers or ranchers so often portrayed today as the typical Westerner (H.Ingram and M.Wallace 1996). Further, as C. S. Lewis (1947:55) observes: "what we call man's power over nature turns out to be a power exercised by some men over other men with nature as its instrument."

In addition, instrumental rationality, undergirds most decisions concerning natural resources (A.Schneider and H.Ingram 1994). Instrumental rationality serves to buttress the attitude of mastery over nature, emphasizing means over ends, production over stewardship, and outputs over ecological conditions. Dryzek has written extensively on the implications of instrumental rationality on natural resource policy and on society. $\mathrm{He}$ concludes that it destroys the more "congenial, spontaneous, egalitarian" aspects of human life, that it is antidemocratic and repressive, and that it "makes effective and appropriate policy analysis impossible" (J.Dryzek 1990a:6). For example, rational planning became a

15. Lutz (1992:154) defines a myth as "a shared story or narrative that provides a common understanding of a civil society's origin, its long-term goals, the justification of institutions, and some sense of a connection with transcendent value or values shared by a people." According to Tudor: "A myth, I suggest, is an interpretation of what the mythmaker rightly or wrongly takes to be hard fact. It is a device men adopt in order to come to grips with reality; and we can tell that a given account is a myth, not by the amount of truth it contains, but by the fact that is believed to be true and, above all, by the dramatic form into which it is cast" (as cited in D. Lutz 1992:154).

16. Stegner's observation rings particularly true in relation to the stalemate over grazing fees in the U.S. Senate in 1993. A bipartisan group of Western senators successfully held a three-week filibuster against rangeland reforms and increases in grazing fees proposed by Secretary Bruce Babbitt. They argued that the increase would damage rural economies and spell the demise of the independent rancher, although only 12 percent of the top 500 lease-holders who graze on federal land are small ranchers. The majority of the permits are owned by large corporations, including Metropolitan Life Insurance Company with 800,000 acres under its control, the J.R. Simplot Company of Idaho with permits for 964,000 acres, one rancher in California with permits for 5 million acres, the Mormon Church, a Japanese conglomerate, and some of the wealthiest families in America (T.Egan 1993:A8). 
justification for distributing water to the privileged, which exacerbated rather than narrowed economic and social differences (H.Ingram and M.Wallace 1996).

Science rooted in positivism has also profoundly shaped resource management in the American West. The science of natural resource management has become increasingly utilitarian and reductionist. In "The Domination of Nature," Leiss explores how the idea of striving for mastery and control over nature has shaped and affected the sciences. Leiss documents a shift in the seventeenth century, which he largely attributes to the attitude of Francis Bacon toward nature. He argues that during this century, there was a "drastic separation of theoretical and practical activity, which from its point of origin in Greek philosophy had permeated all of Western culture until that time" (W.Leiss 1974:150). In the management of natural resources in the western United States, positivistic science has fostered a reliance on expert opinion and technology to solve resource problems, primarily through the "scientific calculation of material benefits" (S.Hays 1959:249). Further, this reliance on expert opinion has had significant consequences for the role of the public in decisions about resources; democratic processes have been ignored in favor of scientific decision-making, leaving little room for the public to participate meaningfully in decisions about resource use and management (H.Ingram and M.Wallace 1996).

In sum, scientific decision-making and instrumental rationality, coupled with a desire to master nature, have profoundly shaped natural resource policy in the American West. Instrumental reason, particularly defined in economic terms, predominates resource decision-making. Formulating resource decisions in these terms has had significant implications for society as a whole. For instance, natural resource institutions, in particular, have been described as insular, hierarchial, output oriented, and protective of turf. ${ }^{17}$ Many citizens feel increasingly alienated from political arenas in which they wield little or no power.

Moreover, environmental degradation in the American West also reflects the dark side of the Enlightenment foreshadowed by Horkheimer, Adorno and Marcuse. Throughout the western United States, rivers have been dammed to flow no more, groundwater aquifers have been overdrawn, range lands are damaged, and riparian areas have been denuded; old growth forests and native salmon are disappearing. Although we have undoubtedly made progress in conservation and preservation efforts over this century, much of present natural resource policy reflects the risks identified by the critical theorists.

\section{Ecosystem Management}

American attitudes toward the environment are changing. In part this shift can be attributed to demographics. Although hunters, fishers, and sometimes wealthy individuals have challenged the management of public lands since the turn of the century (S.Fox 1981), it was not until World War II that general public attitudes toward the nation's public lands began to alter significantly. During this period, the United States grew in affluence, in terms of leisure time and real personal income, and educational levels increased (S.Hays 1987). Increasingly, Americans began turning to the nation's public lands for recreational, aesthetic, ecological, spiritual, and other noncommodity uses. This shift in public values and perceptions, expressed in the growth of the environmental movement,

17. These forces can leave an agency employee feeling "in a great many cases he is only a small cog in a ceaselessly moving mechanism which prescribes to him an essentially fixed route of march" (M.Weber 1968:986). 
has intensified resource conflicts. No longer can land and water be managed solely for animal-unit months, board-feet, or numbers of irrigated acres.

Ecosystem management is proposed as a way to improve natural resource management. Presently, ecosystem management is much more of an emerging management philosophy than a set of specific management practices. New natural resource practices are currently being tested across the country through on-the-ground research and management projects (I.Frentz et al. 1995; B.Boyle et al. 1994; FEMAT 1993; W.Shands et al. 1993).

Five principle themes were revealed in a 1993 literature review of ecosystem management, which includes writings in the areas of adaptive management, conservation biology, ecosystem management, integrated environmental management, and a miscellany of social science literature (M.Moote et al. 1994). These themes, of course, do not wholly represent the philosophy of ecosystem management, but they are a useful starting point.

The first theme is that desired ecological states and the means of achieving them are socially defined. This reflects a recognition that many scientific concepts, including the definition of an ecosystem and criteria for a healthy ecosystem, are essentially value judgments (B.Norton 1992:35). Ecosystem boundaries themselves are social constructions (K.Lee 1993). As Holling argues, the research necessary for the assessment of ecosystems must be focused through social concerns: "The interests of scientists are usually quite narrow and reflect the particular history of a discipline. There is thus no guarantee that in a scientific study the appropriate variables or processes will be measured, or that information will be collected on the proper spatial and temporal scales to address management questions" (C.S. Holling 1978:4).

This theme also includes a recognition that managing human societies is part of maintaining healthy ecosystems (G.Francis 1993; D.Iverson 1993a). Although grounded in the ecological sciences, ecosystem management has a large social component. It is as much a social endeavor as it is a scientific endeavor. Moreover, it is a very political process. In our democratic society, the public itself must decide what values to place on the issues surrounding ecosystem management.

The second theme includes a focus on protecting and restoring critical components, functions, and structures of ecosystems while viewing the system as a whole. "The ecosystem approach... opposes the classical idea that the world can be analyzed as separate, independent parts" (R.Thomas et al. 1988:41-42). Instead, "drawing heavily upon ecological and biological sciences, particularly the field of conservation biology, ecosystem management views the land and resource base in its entirety, as a holistic or integrated entity" (R.Keiter 1993:1). The third theme is related to the second and states that an ecosystem approach to resource management requires management on larger spatial and longer temporal scales than has been the norm in resource management. Understanding diversity of genes, species, and ecosystems requires examination on different spatial and temporal scales (J.Lubchenco et al. 1991:389). Under an ecosystem management perspective, "we must take special care... to avoid near term resource management decisions that may overly restrict or foreclose future management options" (V.Sample et al. 1993:6).

The need for integrated data collection and planning implied by the third theme leads to the fourth: Ecosystem management is characterized by open communication and collaborative decision building. "The very nature of ecosystems dictates that broad, cooperative, and integrated approaches to ecosystem management have to be developed" (V. Gilbert 1988:182). Indeed, some claim that they cannot conceive of any way in which 
an "ecosystem approach could be implemented in jurisdictions with opposing attitudes, institutions, laws, and behaviors -- except perhaps in an altruistic spirit of dedicated cooperation" (J.Vallentyne and A.Beeton 1988:61). The need to integrate the knowledge and values of such a broad array of organizations and individuals implies a need to join organizational and community planning (M.Shannon 1993).

The fifth theme is that institutions need to be adaptable, to reflect both the dynamic nature of ecosystems and the experimental nature of ecosystem management (Cortner et al. 1996). "Given the complexities and uncertainties inherent in the biophysical and social systems that make up ecosystems, sustainable management can only be achieved if management institutions have strong learning capacities" (R.McLain 1993:Executive Summary). An ecosystem approach to resource management will require administrative flexibility, for "no set of goals should be so firmly adopted that institutional adaptability is lost" (J.Agee and D.Johnson 1988:229).

Few researchers embrace all of these themes; in fact, there are contradictions within the literature on ecosystem management (M.Wallace et al. 1996). For example, the need to address resource management on broader temporal and spatial scales and the need to integrate data collection and monitoring seem to conflict with calls for decentralization of power and authority. Overall, however, the five themes reflect the parameters of ecosystem management.

Ecosystem management indicates changes will be required in the way scientists, agencies, and the public participate in decisions about resources (H.Cortner and M.Shannon 1993; J.Sirmon, W.E.Shands, and C.Ligett 1993). Ecosystem management calls for open communication and decision-making, community and organizational learning, and cooperative approaches to management that cross jurisdictional boundaries. New approaches to resource management such as ecosystem management will not succeed if American society and resource institutions remain wedded to vestiges of Enlightenment thought without a critical exploration of both its negative and positive aspects. The development of new theoretical principles that retain the best of Enlightenment thought but discard its dark side will be needed. The following sections discuss alternative conceptions of the four dimensions outlined by the critical theorists: the relationship between humans and nature, an expanded concept of reason, different methods of scientific inquiry, and new social relations among humans.

\section{Humans and Nature}

A key theme of the critical theorists is that much of the human-nature relationship has been defined by an attitude of domination and mastery. This attitude framed the allocation and management of resources for much of the last century in the American West. In the literature on the relationship between humans and nature, this view is generally described as anthropocentric, which can be defined as a view in which "values, goods and interests promote human welfare to the near exclusion of competing nonhuman values, goods, and interests" (E.Katz and L.Oechsli 1993:50). In contrast, ecosystem management, with its emphasis on maintaining and restoring ecological functions and protecting biodiversity, will require a redefinition of the relationship between humans and nature.

One alternative is an ecocentric approach. Under this approach, human goals are pursued in a manner that "recognizes the moral standing of the nonhuman world and seeks to ensure that it, too, may unfold in its diverse ways" (R.Eckersley 1992:26). An ecocentric approach includes a belief that species, organisms and ecosystems have an 
intrinsic value of their own. This strand of thought also includes deep ecology, a view in which realignment of attitudes toward the environment begins with the self (G.Sessions 1990; W.Fox 1990; A.Naess 1989). ${ }^{18}$ Another alternative described by Dubos (1973) is a relationship that is symbiotic. Rather than the instrumental approach toward nature described by the critical theorists, this approach seeks a synthesis of the human and nonhuman world, arguing that in essence, they are one. As Dubos (1973:54) observes,

\begin{abstract}
Conservation programs, whether for wilderness or for man-made environments, are usually formulated and conducted as if their only concern were to the human species and its welfare. Yet they can be effective only if they incorporate another dimension, namely, the earth and her welfare. This is not sentimentality but hard biological science. Man and the earth are two complementary components of an indivisible system. Each shapes the other in a wonderfully creative symbiotic and cybernetic complex.
\end{abstract}

Rather than the domination of nature by humans, humans are viewed as part of nature, not apart from nature.

Di Norcia (1974:89) similarly argues for "a more ecological and fraternal but still rational conception of the science and ethics of nature," for "in reality we cannot fundamentally separate man from nature, or speak of them as controller and controlled." He argues that the technical control of nature cannot be maintained because ecological problems have largely been a product of the successes of technology in "controlling nature' for human ends." The solution for Di Norcia is to "formulate an alternative, ecologically sound conception of this human interest... that should not and can not be an irrational anti-scientific conception; nor should it be limited solely to scientifically based knowledge and practices" (V.Di Norcia 1974:91). A symbiotic approach to resource management is also espoused by Dryzek who contends that "in the long run, only species that affect their environment positively can survive; the relationship is symbiotic as humans need not be either Nature's master or slave" (J.Dryzek1987:46).

These alternative conceptions move away from the traditional view that "nature in general is viewed as a 'natural resource,' as a collection of materials lacking any inhibiting sacredness or intrinsic value as a resource for the satisfaction of human desires" (J.Rodman 1980:61). An attitude of stewardship, not domination, toward nature, is a more

18. In "Environmentalism and Political Theory: Toward an Ecocentric Approach," Robyn Eckersley (1992) reviews a number of theoretical approaches including critical theory, ecosocialism, ecoanarchism, and ecofeminism to search for the theoretical underpinnings of a "green perspective." She argues for an ecocentric as opposed to anthropocentric approach. She proposes two criteria for an ecocentric approach: a commitment to population reduction and the preservation of wilderness. She reviews a number of theoretical perspective along this ecocentric-anthropocentric distinction and concludes that only ecoanarchism associated with Murray Bookchin is an ecocentric perspective. Critical theory is dismissed by Eckersley as too anthropocentric primarily because she bases her assessment on the work of Habermas, not the early critical theorists discussed in this paper. 
appropriate relationship between humans and the environment for the challenges of the coming century.

\section{A Renewed Sense of Reason}

Particularly if the relationship between humans and nature is changed from one of domination to stewardship, ecosystem management, calls for an expanded conception of reason. As the critical theorists argue, the Enlightenment produced a narrow conception of reason, instrumental rationality, which gives little or no thought to the reasonableness of the ends sought. In contrast, ecosystem management will require a direct examination of the ends sought. It requires society, as a whole, to determine the goals of resource management. Questions concerning social values and community concerns cannot be answered without an examination of ends. The choices that need to be made cannot be made through instrumental reason because social decisions are more than the product of choosing among policy options. A shared effort within the larger community is needed to find common ground on what are reasonable ends. ${ }^{19}$

Alternative models of rationality suggested in the literature can be drawn upon for ecosystem management. For example, Leiss calls for rationality to include freedom and autonomy (W.Leiss 1974). Tribe (1973) argues for a new type of reason -- one undertaken in public with a public character. Other ideas can be drawn from Jürgen Habermas, a contemporary critical theorist. In his writings, Habermas takes critical theory in quite a different direction than originally proposed by the early critical theorists, primarily in the way he construes the relationship between humans and nature. Instead, Habermas is concerned primarily with domination in the social world and he constructs another type of rationality, communicative rationality, for social relations. Unlike the early theorists, Habermas believes that through communicative rationality, the needs of the natural world will be recognized and incorporated. In fact, in contrast to the early critical theorists, Habermas argues that it is appropriate to approach the natural world using instrumental rationality. ${ }^{20}$

Communicative rationality is based in speech and found through interactions between people based upon communication. For Habermas, "life is (only) rational when people, in awareness of constraints and restrictions of their life-situation, determine the collective social goals and values" (J.Habermas 1992:82). He believes that under conditions of no

19. The full quote by Tribe (1973:618) is: "I believe we will find that the largest questions which instrumental rationality cannot answer are questions which will remain unanswerable so long as one adheres to a conception in which objectives and choices are regarded as things ("objects") selected by the actor (the "subject") on a basis which must always rest on an irreducibly arbitrary and subjective element. Any such conception must fail in one of two ways -- either it must ignore the crucial respects in which a person's or community's 'chosen' actions alter the characteristics of the chooser -- or, if it does not ignore them, it must yield a disconnected notion of the chooser as a series of selves lacking temporal continuity and of persons as objects profoundly isolated, sharing nothing truly personal and yet enduring with one another."

20. It is a point of contention among modern theorists as to how much hope the early critical theorists held out for the Enlightenment era and the resurrection of reason (See C.Rocco 1994). 
coercion, equal knowledge among people, and no influences from power structures, people can construct communicative rationality. For Habermas "the forceless force of the best argument wins."

For the natural world, Habermas believes that instrumental rationality is the appropriate way to make decisions concerning nature (J.Whitebrook 1979). In fact, one of his primary concerns is not to discard instrumental rationality as he believed the early critical theorists did; his interest is to reduce its prevalence in the social world and confine it to its proper realm. He proposes a dualistic framework in which "the logic of instrumental rationality governs the domination of external nature, and the logic of communicative rationality governs that of internal nature" (J.Whitebrook 1979:43). ${ }^{21}$

In an effort to reconcile these differences, John Dryzek offers another type of rationality called "ecological rationality" or "green reason" (J.Dryzek 1987; 1990b). Dryzek (1990b) incorporates the communicative rationality of Jürgen Habermas and also the political elements described by Tribe to create a discursive and democratic rationality that also recognizes the importance of the natural world in more than instrumental terms. Dryzek $(1987,1990 b)$ argues that communicative rationality can be expanded to include the natural world. This type of rationality requires discovering ecological principles and in turn incorporating these principles into decisions about natural resources. Further, investigation to find these principles is undertaken largely through "negotiations with nature" and the gradual understanding built through interactions between humans and the natural world (E.Bird 1987:259).

Ecosystem management will require a rationality similar to that constructed by Dryzek. As proposed, developing an ecological rationality is an interactive and adaptive process with the human dimensions of resource management tied directly to our ability to interact and learn about the natural world. It is a process of interaction with the natural world through science, but in a social context. It also requires a new, and more accurate, concept of the actual way humans reason. It may require accepting the idea "that reason may not be as pure as most of us think or wish it were, that emotions and feelings may not be intruders in the bastion of reason at all; they may be enmeshed in its networks, for worse and for better" (A.Damasio 1994:xii, emphasis in original). This concept of rationality calls for the integration of the elements of discursive democracy of Dryzek, the public character defined by Tribe, the aesthetics of Marcuse, and other qualities, most notably human imagination and an ability to acknowledge the sublime.

\section{Science}

An attitude of stewardship with nature as well as a richer conception of rationality also suggests that changes in scientific inquiry are in order. As proposed, ecosystem

21. Habermas addresses the issue of whether a new relationship with nature is needed and definitively decides not. He does not share the views of the Frankfurt theorists that to address societal ills, a new relationship between humans and nature is needed. He particularly does not believe a shift is needed from using instrumental rationality when approaching nature. As Whitebrook (1979:41) notes, Habermas challenges the main thesis of Horkheimer, Adorno, and Marcuse that the way out of the "historical impasse of our time -- however unlikely -- requires reconciliation with nature." 
management requires the integration of political and social factors with scientific information. As noted earlier in this paper, today's science has become increasingly utilitarian and reductionist in nature.

It will be difficult to integrate political and social factors as required by ecosystem management with traditional modes of scientific inquiry. Compartmentalization, specialization, and separation are characteristics of modern academic life. As MacIntyre (1984:61) observes:

It is because the habits of mind engendered by our modern academic curriculum separate out the history of political and social change (studied under one set of rubrics in history departments by one set of scholars) from the history of philosophy (studied under quite another set of rubrics in philosophy departments by quite another set of scholars) that ideas are endowed with a falsely independent life of their own on the one hand and political and social action is presented as peculiarly mindless on the other.

Changes in scientific inquiry will require new methods and research questions and new roles for scientists, some of whom can barely communicate across disciplines because of jargon and notions of academic supremacy. Agger (1991), for example, argues that academics have played a large part in the general decline of scientific discourse and argues they have a responsibility to speak plainly. As he explains, "most importantly, we must democratize expert cultures of all sorts, including the culture of theory" (B.Agger 1991:138, emphasis in original). Academicians must begin to understand the "mammoth structuring forces invading and constituting our lives" and expand the public discourse on these forces to discern sources of domination in the social world (B.Agger 1991:138). Theorists, in particular, have a responsibility to speak in terms other disciplines can understand.

Ecosystem management will also clearly require an effort to address the split in paths between the social and natural sciences and between theory and practice. As proposed under ecosystem management, management practices will be forged through a mix of theory and practice, on-the-ground experimentation, and multidisciplinary cooperation. Under this type of approach, inductive reasoning, which emphasizes observation rather than general principles, needs to be reemphasized. ${ }^{22}$ This emphasis on inductive, rather than deductive reasoning, goes directly against the heritage of Enlightenment science. As Rocco (1994:8) contends, "The aim of Enlightenment is the subsumption of all particulars under the general, the substitution of formula for concept, rule and probability for cause and motive." Ecosystem management will sometimes require the subsumption of the general to the particular; the specific characteristics of a place may be more important than following a general principle. Finally, ecosystem management requires the examination of social values. It requires answers to questions such as: Does nature have an intrinsic value of its own? Do animals and plants have "rights?" Can species be chosen for extinction?

22. Schneider and Ingram (1994:44) discuss inductive reasoning: "An inductive theory, on the other hand, is grounded in observations. The analyst observes the empirical world, interprets its meanings, and searches for principles or more general laws that will explain observations and their relationships to each other." 


\section{Social Institutions}

Underlying ecosystem management is an appeal for a restructuring of society's institutions. In modern society, social domination and hierarchy are instilled in our social institutions and in the "normative patterns embedded in and enforced by laws and mores (informal customs and practices)" (R.Bellah et al. 1992:11). Social institutions in many respects reinforce patterns of domination in relationships among humans. Ironically, as Rosenau (1992:101) notes, "those institutions that made rational discussion possible in the past and guaranteed the integrity of the public sphere (freedom of speech, assembly, and communicating) today undermine it." For example, the public agencies charged with resource management too often define the initial bounds of a conflict and the preferred set of options, greatly limiting the participation of the public.

Ecosystem management, with its emphasis on consensual decision-making, social learning, and cooperative approaches to resource management, implies much different social relationships. Rather than domination, the relationship suggested is one of interdependence. This interdependence is also suggested as a result of a new relationship with nature based upon stewardship. Under this view, humans are interdependent in the context of their relationship with the natural world. It is a much different picture of social relations than the social domination traditionally found in resource management where powerful interests often collude in closed arenas, leaving little room for meaningful participation of members of the public.

An interdependence in social relations suggests a shift in emphasis from the individual to the community; a renewed conception of public life is called for (M.Shannon 1993; M.Stanley 1990). Writers as diverse as MacIntrye, Foucault (1979), and Habermas have noted the lack of a public place, or public sphere where people can deliberate. ${ }^{23}$ For example, in contrast to Aristotelian society, "we lack, as they did not, any public, generally shared communal mode either for representing political conflict, or for putting our politics to the philosophical question"(A.MacIntyre 1984:138, emphasis in original). With the withering of this public sphere comes a new responsibility for citizens to create democratic conditions. What is needed is "a public space where individuals can congregate and confront the state" (J.Dryzek 1990a:220). Professional groups, private groups, and citizens, as well as public agencies, must work to create this discourse. Innovative and different ways to engage citizens in policy-making are called for (H.Cortner and M.Shannon 1993). Public deliberation over issues is needed to provide a chance for people to "come out from their homes and interact in public life" (Kettering Foundation 1993). It is also of utmost importance that people are free to meet and congregate without governmental control and interference.

Finally, ecosystem management will require an evaluation and deliberation of social values to discover ways to overcome human social domination. As argued earlier, governance and institutional structures and functions are influenced by how the relationships among humans and the natural world, and among humans themselves, are defined. Forms of governance that are proposed range from the Hobbesian government,

23. Agger (1990) credits Plato for originating the notion of a public sphere. Rosenau (1992:101) describes it as a place where citizens can debate and deliberate separate from the state in an effort to seek a "judicious, wise, thoughtful agreement about society's needs and the best policy for a nation." 
envisioned by Ophuls (1974) and other ecological writers, who argue the necessity of a large centralized government as a precondition to improved ecological conditions to more decentralized and participatory models that organize around local ecological conditions (J.Rodman 1980; D.Orr and S.Hill 1978; P.Stillman 1974). In fact, much of the literature on ecosystem management calls for a bottoms-up approach with an emphasis on increased empowerment and organization of local communities (G.Beneviste 1989). Under models such as these, all actors with a stake in resource decisions, even if peripheral, are represented continuously throughout the planning and development process. Agencies also have a responsibility to draw into the process those groups traditionally left out (L.Fortman and C.Lewis 1987). In fact, new institutions are needed "in which responsibility and authority are distributed widely among the citizenry and in which all individuals are encouraged to develop their critical faculties" (W.Leiss 1974:197).

\section{Paths for Future Action}

Ecosystem management is concurrently developing at the level of practice as well as the level of theory. Table 1, below, outlines some fundamental changes. A number of scholars have recently published collections of case studies of ecosystem management projects (J.Wondolleck and S.Yaffee 1994; V.Sample et al. 1995; I.Frentz et al. 1995; Natural Resources Law Center 1996). These case studies represent just a sampling of the profusion of recent efforts focused on ecological sustainability, collaborative planning and decision-making, and alternative approaches to resource management, all of which are evidence that ecosystem management is beginning to be realized in practice.

Many of these projects share characteristics that reflect the theoretical principles discussed above. For example, many are grassroots, bottoms-up efforts composed of neighbors, and they often taken the form of loosely organized, non-governmental community organizations. These endeavors strive to include all people with a concern for the land, from land owners to Indian tribes to government agencies to community groups. Indeed, some of the most successful efforts are those that involve the formation of "unlikely coalitions," grassroots groups that bring together diverse people with very different views about how land should be managed. In San Luis Valley, Colorado, for example, local, state and federal agencies, private landowners, and environmental and commodity interest groups organized to address the common goal of sustaining ecological, social, and economic sustainability in the valley (I.Frentz, et al. 1995:A-121). By opening decision-making processes to a wider set of interests than has previously been typical in natural resource management, projects such as these are evidence of changing social relations. Many such efforts claim success because they build better relationships among individuals, groups, and agencies, thereby fostering cooperation rather than adversity (J.Wondolleck and S.Yaffee 1994, emphasis added). These efforts represent a type of politics that begins with the citizenry; it is the relationships and institutions that people form that become the source of political power (W.Greider 1992).

In fact, these community-based groups are explicitly moving away from expert decision-making and the use of instrumental rationality to make decisions about resources. The Owl Mountain Partnership in Colorado, for example, is a collaborative effort among private landowners and land management agencies who together identify priority resource management issues and undertake planning and management to address these issues. As is 
TABLE 1. Changes in Science and Politics (adapted from Iverson 1993b)

\begin{tabular}{|c|c|c|}
\hline & Enlightenment Thought & Ecosystem Management \\
\hline Nature & Domination, mastery. & Harmony, synthesis, interrelated. \\
\hline \multirow[t]{2}{*}{ Decision-making } & Rigid, chain of command. & $\begin{array}{l}\text { Adapted to context of problem, } \\
\text { interrelated to other problems. }\end{array}$ \\
\hline & $\begin{array}{l}\text { Authoritarian: experts and } \\
\text { professional opinions were the } \\
\text { only ones that counted. Science } \\
\text { provides "the answer." }\end{array}$ & $\begin{array}{l}\text { Deliberated: all stakeholders' } \\
\text { opinions count. Science provides } \\
\text { information. Science alone } \\
\text { cannot provide answers. }\end{array}$ \\
\hline Institutions: & $\begin{array}{l}\text { Hierarchical, top-down } \\
\text { bureaucracies. }\end{array}$ & $\begin{array}{l}\text { Adaptive, bottoms-up, open, } \\
\text { cooperative. }\end{array}$ \\
\hline Management: & $\begin{array}{l}\text { Centralized or decentralized; } \\
\text { rigid, little focus on incentives or } \\
\text { innovation. }\end{array}$ & $\begin{array}{l}\text { Interrelated teams, adaptive, } \\
\text { much focus on incentives and } \\
\text { innovation }\end{array}$ \\
\hline Planning: & Comprehensive, rational. & $\begin{array}{l}\text { Interrelated, chaotic, looking for } \\
\text { order in chaos. Imaginative. }\end{array}$ \\
\hline Participation: & Influence, money. & Discursive, deliberation. \\
\hline Leadership: & $\begin{array}{l}\text { Authoritarian: leaders } \\
\text { designated. }\end{array}$ & $\begin{array}{l}\text { Situational: Leaders arise from } \\
\text { the community when needed. }\end{array}$ \\
\hline \multirow[t]{2}{*}{ Sciences: } & $\begin{array}{l}\text { Deterministic, linear, static, } \\
\text { approaching steady-state } \\
\text { equilibrium. }\end{array}$ & $\begin{array}{l}\text { Stochastic, nonlinear, dynamic: } \\
\text { variable-rate dynamics with } \\
\text { temporary equilibria upset } \\
\text { periodically by chaotic moments } \\
\text { that set the stage for next } \\
\text { temporary equilibrium. }\end{array}$ \\
\hline & $\begin{array}{l}\text { Robust, well-defined theory, } \\
\text { discrete data, and highly } \\
\text { predictable outcomes. }\end{array}$ & $\begin{array}{l}\text { Embryonic, beginnings of } \\
\text { theory, theory and practice, } \\
\text { interrelated data and unreliable } \\
\text { outcomes. "Expect to be } \\
\text { surprised." }\end{array}$ \\
\hline Models: & $\begin{array}{l}\text { Maps, linear optimization, } \\
\text { monetized cost-benefit analysis. }\end{array}$ & $\begin{array}{l}\text { GIS, relational databases, non- } \\
\text { linear simulation (time and space } \\
\text { dependent), evaluation for social, } \\
\text { economic, and political aspects. }\end{array}$ \\
\hline Ethics: & $\begin{array}{l}\text { Compartmentalized, } \\
\text { interrelationships - minor. }\end{array}$ & $\begin{array}{l}\text { Holistic, interrelationships } \\
\text { important. }\end{array}$ \\
\hline Spiritual: & "God is dead" - Nietsche. & "Nietsche is dead" - God. ${ }^{\mathrm{b}}$ \\
\hline
\end{tabular}

a. The full quotation by Nietsche is: "God is dead; but given the way of men, there still may be caves for thousands of years in which his shadow will be shown" as cited in W. Connolly 1988:137.

b. This statement circa the 1960s reflects a perspective by Wuthnow (1992) that Americans are "rediscovering the sacred" in their lives. 
common to many such efforts, planning and management decisions are made by consensus (I.Frentz, et al., 1995:A-107). Dozens of coordinated resource management groups in the West operate on similar principles of openness, mutual respect, and consensus decision-making (C.Cleary and D.Phillippi 1993). As Greider (1992:225) notes, "For them, democracy means building their own political organizations, drawing people together in a relationship that leads to real political power. In a sense, they are reinventing democracy from the ground up, starting in their own neighborhoods."

In short, across the West local landowners are beginning to form partnerships between themselves and with federal agencies, conservation organizations, industry and others to discuss environmental issues and to work on restoration of the ecosystem. At Trout Mountain, Oregon, ranchers have voluntarily reduced stocking levels -- at considerable personal expense -- in order to allow riparian area recovery (D.Hatfield and C.Hatfield 1993). Similarly, in Coos Bay, Oregon, landowners are working to improve salmon habitat, even at the expense of the local timber industry. In a typical mission statement, the Coos Bay Watershed Association states that its purpose is "to provide a framework to promote, coordinate, and implement proven management practices and test promising new management practices, in the interests of watershed health" (Natural Resources Law Center 1996:58, emphasis added). In the San Luis Valley effort cited above, residents, agencies, and interest groups all agree that it is necessary to protect, restore, and maintain biotic diversity to achieve economic and social, as well as ecological, sustainability. Such projects reflect the changing relationship between humans and nature. Increasingly, efforts are being made to recognize that humans are part of ecosystems, not apart from them.

However, these efforts also face daunting obstacles, in the form of entrenched social institutions. For the most part, decisions about resources are still made by a few with little input from many members of the public. As Wilkinson observes, "the law is resolutely protective of established interests, and much of that protectionism is profoundly subtle" (C.Wilkinson 1992:14). The strength of Western Senators in blocking any type of range reform and the recent congressional attacks on environmental legislation are both indicators of the strength of sources of domination and power in environmental politics. Further, the rise of the "Wise Use Movement," county supremacy groups, and citizen militias, and the refusal of some environmental organizations to join in collaborative efforts with industry, show that social divisiveness still characterizes much of the debate over resource management. However, increased community coordination on ecosystem health and sustainability, as shown by the efforts discussed above, holds promise that the influence of established interests on management of many of the nation's resources is beginning to weaken.

\section{Conclusion}

Writing in the 1940s, 1950s, and 1960s, early critical theorists made an important contribution in helping to establish a framework through which to view today's environmental issues. Their emphasis on Enlightenment thought and the examination of how these intellectual forces have played out in modern society not only helps us understand modern society in clearer terms, but also offers pathways for the future. Horkheimer and Adorno, in particular, point out that the Enlightenment has paradoxically brought "liberation and slavery, freedom and constraint, self-conscious transparency and ignorant opacity about what it is we are doing to ourselves, our world, and to others" (as cited in C.Rocco 1994:79) In fact, Enlightenment thought is paradoxical, for "promising 
the subject control and mastery, enlightenment ruthlessly controls and masters the subject" (C.Rocco 1994:80). Further, much of the modern world reflects the one-dimensional society described by Marcuse.

An examination of Western U.S. resource policy lends support to much of the critical theorists' argument. Nature has been transformed into natural resources for either production or as an object of scientific inquiry. Yet, human destiny is not to dominate nature, but "to comprehend it" (M.Horkheimer 1992:47); not to master it, but to liberate it (H.Marcuse 1966). The rise of support for ecosystem management lends credence to the idea that we may now be at a crossroads where "it may be that the scope and depth of the social and ecological crisis are so great that nothing short of an epochal transformation on the scale of world views will be commensurate with them" (J.Whitebrook 1979:69). The philosophy of ecosystem management requires asking ourselves what kind of society, and correspondingly, what kind of relationship with nature we want.

Patterns of politics suggested by ecosystem management include public deliberation of values toward the environment, cooperative solutions, and dispersion of power and authority. These are all avenues to lessen social hierarchy and domination. Through opening the value debate, fostering a sense of interdependence among humans, and renewing a sense of reason, the chains of social domination may be lessened. The changes implied by ecosystem management lend support to much of Horkheimer and Adorno's argument that natural domination is related to social domination; there are links between domination of the natural world and domination in the social world.

Ecosystem management has by no means developed a broad base of support among Americans (R.Cawley and J.Freemuth 1993). Accompanying the changes in the way Americans view land in the West is a vocal, sometimes virulent, debate. Further, the social implications of ecosystem management must be closely examined. As the critical theorists have argued, science is very much a social construction. As Bird observes, "we need to go beyond the notions that scientific negotiation takes place among people and assert that science is engaged with nature in negotiating reality itself... reality is being negotiated at the same time as its theoretical construction" (E.Bird 1987:259).

The challenge for theorists and policy analysts is discerning theoretical principles underlying present resource management and comparing them to the principles proposed under ecosystem management. This paper suggests that this analysis must take place in a much broader historical and theoretical context than has been used in the past. Under this type of analysis, natural resource policy is developed in concert with theory. Theoretical principles can provide benchmarks and evaluative criteria for the design of policies and institutional arrangements. Furthermore, it must be a democratic process. A revived version of critical theory may be able to provide signposts for this challenge, particularly in developing new ways of thinking about the relationship between humans and nature and in relating social and political issues. Critical theory can provide a method to link social processes and political practice, particularly in environmental issues. It can locate the sources of domination, develop alternative visions of the future, and finally, be used to design policy alternatives. 


\section{References}

Agee, James K., and Darryll R. Johnson.

1988. A Direction for Ecosystem Management. In Ecosystem Management for Parks and Wilderness. James K. Agee and Darryll R. Johnson editors. Seattle: University of Washington Press, pp.226-232.

Agger, Ben.

1991. Theorizing the Decline of Discourse or the Decline of Theoretical Discourse. In Critical Theory Now. P. Wexler editor. London: The Falmer Press,pp.118-144.

Aplet, G.H., T. Olson, and V.A. Sample. editors. 1993. Defining Sustainable Forestry. Covelo, California: Island Press.

Bellah, Robert, Richard Madsen, William M. Sullivan, Ann Swidler, and Steven M. Tipton

1992. The Good Society. New York: Alfred A. Knopf.

Beneviste, Guy.

1989. Mastering the Politics of Planning. San Francisco: Josey-Bass.

Bird, Elizabeth Ann R.

1987. The Social Construction of Nature: Theoretical Approaches to the History of

Environmental Problems. Environmental Review Winter:255-264.

Boyle, Brian J., Margaret A. Shannon, Robert A. Rose, Kathleen Halvorsen, and H. Stuart Elway.

1994. Policies and Mythologies of the U.S. Forest Service: A Conversation with Employees. Research Report prepared for Director, Pacific Northwest Experiment Station and Chief, USDA Forest Service. Seattle: Institute for Resources in Society, College of Forest Resources, University of Washington.

Brown, F. Lee, and Helen Ingram. 1987. Water and Poverty in the Southwest. Tucson: University of Arizona Press.

Cawley, R. McGreggor, and John Freemuth. 1993. Tree Farms, Mother Earth, and Other Dilemmas: The Politics of Ecosystem Management in Greater Yellowstone. Society and Natural Resources 6:41-53.

Cleary, C. Rex, and Dennis Phillippi.

1993. Coordinated Resource Management Guidelines. Denver: Society for Range Management.

Commager, Henry Steele

1977. The Empire of Reason: How Europe Imagined and America Realized the Enlightenment. Garden City: Doubleday.

Connolly, William E.

1988. Political Theory and Modernity. New York: Basil Blackwell.

Cortner, Hanna J., and Margaret A. Moote.

1992. Sustainability and Ecosystem Management: Forces Shaping Political Agendas and Public Policy. In American Forestry--An Evolving Tradition. Proceedings of the Society of American Foresters National Convention, Richmond, VA. October 2527,1992. Bethesda, Maryland: Society of American Foresters, pp.310-316.

Cortner, Hanna J., and Margaret A. Shannon.

1993. Embedding Public Participation in its Political Context. Journal of Forestry, 917:14-16. 
Cortner, Hanna J., Margaret Shannon, Mary G. Wallace, Sabrina Burke, and Margaret Moote.

1996. Incentives and Barriers for Ecosystem Management: A Problem Analysis. GTR354. Portland, Oregon: USDA Forest Service Pacific Northwest Research Station.

Curry-Roper, Janel M. and Steven McGuire.

1993. The Individualistic Imagination and Natural Resource Policy. Society and Natural Resources, 6:259-272.

Damasio, Antonio.

1994. Descartes' Error: Emotion, Reason, and the Human Brain. New York: G.P.Putnam.

Di Norcia, Vincent.

1974. From Critical Theory to Critical Ecology. Telos 22:85-95.

Dryzek, John.

1987. Rational Ecology. Oxford: Basil Blackwell.

1990a. Discursive Democracy: Politics, Policy, and Political Science. Cambridge: Cambridge University Press.

1990b. Green Reason: Communicative Ethics for the Biosphere. Environmental Ethics,12:195-210.

Dubos, Rene.

1973. A Theology of Earth. In Western Man and Environmental Ethics. Ian Barbour, editor. Massachusetts: Addison-Wesley, pp.43-54.

Eckersley, Robyn.

1992. Environmentalism and Political Theory: Toward an Ecocentric Approach. Albany: State University of New York Press.

Egan, Timothy.

1993. Wingtip Cowboys in Last Stand to Hold on to Low Grazing Fees. The New York Times Vol. cxliii, no. 49,499, October 29, 1993:A8.

Erlich, P. and A. Erlich. 1992. The Value of Biodiversity. Ambio 21(3):219-226.

FEMAT -- Forest Ecosystem Management Assessment Team.

1993. Forest Ecosystem Management: An Ecological, Economic, and Social Assessment.Washington D.C.: U.S. Government Printing Office.

Forester, John.

1985. Introduction: The Applied Turn in Contemporary Critical Theory. In Critical Theory and Public Life. John Forester editor. Cambridge: MIT Press, pp. 1-11.

Fortman, Louise, and Connie Lewis.

1987. Public Involvement in Natural Resource Management. Berkeley, CA, Unpublished manuscript. On file at the Water Resources Research Center, University of Arizona, Tucson, Arizona.

Foucault, Michel.

1979. Discipline and Punish. New York, U.S.: Vintage Books.

Fox, Stephen.

1981. The American Conservation Movement: John Muir and his Legacy. Madison: University of Wisconsin Press. 
Fox, Warwick.

1990. Toward a Transpersonal Ecology: Developing New Foundations for Environmentalism. Boston: Shambala.

Francis, George.

1993. Ecosystem Management. Natural Resources Journal 33:315-345.

Franklin, J.F.

1993. The Fundamentals of Ecosystem Management with Applications in the Pacific Northwest. In Defining Sustainable Forestry. G.H. Aplet, N. Johnson, J.T. Olson, and V.A. Sample editors. Island Press, Covelo, California: pp.127-144.

Frentz, Irene, Paul Hardy, Sussanne Maleki, Ali Phillips, and Barbara Thorpe.

1995. Ecosystem Management in the U.S.: An Inventory and Assessment of Current Experience. Ann Arbor: University of Michigan, School of Natural Resources and the Environment.

Gay, Peter.

1969. The Enlightenment: An Interpretation - Vol. II: The Science of Freedom. New York: Alfred A. Knopf.

Gilbert, Vernon.

1988. Cooperation in Ecosystem Management. In Ecosystem Management for Parks and Wilderness. James K. Agee and Darryll R. Johnson editors. Seattle: University of Washington Press, pp.180-192.

Goodin. Robert.

1982. Political Theory and Public Policy. Chicago: University of Chicago Press.

Greider, William.

1992. Who Will Tell the People: The Betrayal of American Democracy. New York: and Schuster.

Grumbine, Edward.

1994. What is Ecosystem Management? Conservation Biology 8:27-38.

Habermas, Jürgen.

1992. The Philosophical Discourse of Modernity. Cambridge: MIT Press.

Hamilton, Elizabeth.

1976. The Voice of the Spirit: The Spirituality of St. John of the Cross. Great Britain:

Darton, Longman, and Todd.

Hartz, Louis.

1955. The Liberal Tradition in America: An Interpretation of American Political Thought Since the Revolution. New York: Harcourt, Brace.

Hatfield, Doc, and Connie Hatfield.

1993. Solutions for the Land and the People. In Riparian Management Strategies: Common Threads and Shared Interests. Barbara Tellman, Hanna J. Cortner, Mary G.Wallace, Leonard F. DeBano, and R.H. Hamre, editors. Technical Report RM226.U.S. Forest Service, Rocky Mountain Forest and Range Experiment Station: Fort Collins, pp. 147-153.

Hawthorn, Geoffrey.

1976. Enlightenment and Despair: A History of Sociology. Cambridge: Cambridge University Press.

Hays, Samuel.

1987. Beauty, Health and Permanence: Environmental Policies in the United States,1955-1985. Cambridge: Cambridge University Press. 
Hays, Samuel.

1959. Conservation and the Gospel of Efficiency. Cambridge: Harvard University Press.

Holling, C. S.

1978. Adaptive Environmental Assessment and Management. London: John Wiley and Sons.

Horkheimer, Max.

1947. The Eclipse of Reason. New York: Oxford University Press.

1992. The End of Reason, in Andrew Arato and Eike Gebhardt, editors. The Essential Frankfurt School Reader. New York: Continuum, pp.26-48.

Horkheimer, Max, and Theodor Adorno.

1993. Dialectic of Enlightenment. New York: Continuum.

Hulme, Peter and Ludmilla Jordanova.

1990. Introduction. In The Enlightenment and its Shadows. Peter Hulme and Ludmilla Jordanova, editors. Great Britain: T.J. Press.

Ingram, Helen, and Mary G. Wallace.

1996. An Empire of Liberty: Thomas Jefferson and Governing Natural Resources. In Thomas Jefferson and the Changing West: From Conquest to Conservation. Missouri: Missouri Historical Society Press. Forthcoming, Spring 1997.

Interagency Ecosystem Management Task Force.

1995. The Ecosystem Approach: Healthy Ecosystems and Sustainable Economies: Volume 1 - Overview. Springfield: National Technical Information Services.

Iverson, Dave.

1993a. An Ecosystems Approach to Management: Moving From Old Standards to New Standards, Updated and Expanded on 2/29/30, Ecowatch 4/8/93: p. 1. On file at the Water Resources Research Center, University of Arizona, Tucson, Arizona.

1993b. Framework for a Shared Approach to Ecosystem Management, Unpublished manuscript, September 1. 1993. On file at the Water Resources Research Center, University of Arizona, Tucson, Arizona.

Jordanova, Ludmilla.

1990. The Authoritarian Response. In The Enlightenment and its Shadows. Peter Hulme and Ludmilla Jordanova, editors. Great Britain: T.J. Press, pp. 200-216.

Kant, Immanuel.

1990. Foundations of the Metaphysics of Morals, and What is Enlightenment? New York: Liberal Arts Press.

Katz, Eric, and Lauren Oechsli.

1993. Moving beyond Anthropocentrism: Environmental Ethics, Development and the Amazon. Environmental Ethics, 15:49-73.

Keiter, Robert B.

1993. Beyond the Boundary Line: Ecosystems and Law on the Public Domain, Paper presented at A New Era for the Western Public Lands. Natural Resources Law Center, University of Colorado, Boulder, Colorado. September 19-21, 1993. On file at the Water Resources Research Center, University of Arizona, Tucson, Arizona.

Kellner, Douglas. 1989. Critical Theory, Marxism, and Modernity. Cambridge: Polity. 
Kettering Foundation.

1993. Meaningful Chaos: How People Form Relationships with Public Concerns.Prepared by the Harwood Group for the Kettering Foundation. Dayton, Ohio: Kettering Foundation.

Lee, Kai.

1993. Compass and Gyroscope: Integrating Science and the Environment. Covelo, California: Island Press.

Leiss, William.

1974. The Domination of Nature. Boston, U.S.: Beacon Press.

Lenhardt, Christian.

1976. The Wanderings of the Enlightenment, In On Critical Theory. John O'Neill, editor. New York: Seabury Press, pp.34-57.

Leonard, Stephen.

1991. Critical Theory in Political Practice. Princeton: Princeton University Press.

Lewis, C.S.

1947. The Abolition of Man. New York: Macmillan.

Lukacs, Georg.

1971. History and Class Consciousness. Cambridge: MIT Press.

Lubchenco, J., A. Olson, L. Brubaker, S. Carpenter, M. Holland, S. Hubbell, S. Levin,

J.MacMahon, P. Matson, J. Melillo, H. Mooney, C. Peterson, H. Pulliam, L. Real, P.Regal, and P. Risser.

1991. The Sustainable Biosphere Initiative: an Ecological Research Agenda. Ecology, 72(2):371-412.

Lutz, Donald S.

1992. A Preface to American Political Theory. Lawrence: University of Kansas Press.

MacIntyre, Alasdair.

1984. After Virtue. Indiana: Notre Dame Press.

Marcuse, Herbert.

1966. One-Dimensional Man. Boston: Beacon Press.

Marx, Karl.

1978. For a Ruthless Criticism of Everything Existing. In The Marx-Engels Reader, 2ndedition. Robert C. Tucker editor. New York: W.W. Norton, pp.12-16.

McLain, Rebecca.

1993. Toward more Effective Ecological Learning: Procedural Guidelines for the USMAB Landscape Sustainability Project, Draft Manuscript. Seattle: University of Washington, College of Forest Resources.

Moncrief, Lewis.

1973. The Cultural Basis of our Environmental Crisis. In Western Man and Environmental Ethics. Ian Barbour, editor. Massachusetts: Addison-Wesley, pp. 4354.

Moote, Margaret A., Sabrina Burke, Hanna J. Cortner, and Mary G. Wallace. 1994. Principles of Ecosystem Management. Tucson: Water Resources Research Center, University of Arizona.

Morrissey, Wayne, Jeffrey A. Zinn, and Lynne M. Corn. editors.

1994. Ecosystem Management: Federal Agencies Activities. Washington, D.C:Congressional Research Service, Library of Congress.

Naess, Arne.

1989. Ecology, Community, and Lifestyle. Cambridge: Cambridge University Press. 
Natural Resources Law Center. 1996. Watershed Initiatives Sourcebook. Boulder: University of Colorado School of Law, Natural Resources Law Center.

Norton, Bryan G.

1992. A New Paradigm for Environmental Management, Ecosystem Health: New Goals for Environmental Management. Robert Costanza, Bryan G. Norton, and Benjamin D.Haskell editors. Covelo, California: Island Press, pp.23-41.

O’Neill, John. editor. 1976. On Critical Theory. New York: Seabury Press.

O’Neill, Onora.

1990. Enlightenment as Autonomy: Kant's Vindication of Reason. In The Enlightenment and its Shadows. Peter Hulme and Ludmilla Jordanova editors. London, U.K.: Routledge, pp.184-200.

Ophuls, William.

1974. Reversal is the Law of the Tao: The Imminent Resurrection of Political Philosophy. In Environmental Politics. Stuart Nagel, editor. New York: Praeger, pp.34-48.

Orr, David and Stuart Hill.

1978. Leviathan, the Open Society, and the Crisis of Ecology. Western Political Quarterly, 31:457-69.

Reich, Robert. editor. 1988. The Power of Public Ideas. Cambridge: Harvard University Press.

Reisner, Mark. 1986. Cadillac Desert: The American West and its Disappearing Water. New York: Viking.

Rocco, Christopher.

1994. Between Modernity and Postmodernity: Reading "Dialectic of Enlightenment" Against the Grain. Political Theory 221: 71-97.

Rodman, John.

1980. Paradigm Change in Political Science. American Behavioral Scientist 241: 4978.

Rolston, Holmes, III.

1988. Environmental Ethics: Duties to and Values in Nature. Philadelphia: Temple University Press.

Rosenau, Pauline.

1992. Post-Modernism and the Social Sciences. New Jersey: Princeton University Press.

Rousseau, Jean-Jacques.

1987. The Basic Political Writings. Donald A. Cress editor. Indianapolis: Hackett Publishing.

Rowe, J. Stan.

1992. The Ecosystem Approach to Forestland Management. The Forestry Chronicle, 682: 222-224.

Sample, V. Alaric, Anthony S. Cheng, Maia J. Enzer, and Margaret A. Moote. 1995. Building Partnerships for Ecosystem Management on Mixed Ownership Landscapes: Regional Perspectives. Washington, D.C.: The Forest Policy Center. 
Sample, V. Alaric, Nels Johnson, Gregory H. Aplet, and Jeffery T. Olson.

1993. Introduction. In Defining Sustainable Forestry. Gregory Aplet, Nels Johnson, Jeffery T. Olson and V. Alaric Sample editors. Covelo, California: Island Press, pp.310.

Sandel, Michael.

1988. The Political Theory of the Procedural Republic. In The Power of Public Ideas.Robert Reich editor. Cambridge: Harvard University Press, pp.109-122.

Schneider, Anne and Helen Ingram.

1994. Approaches to Policy Design: A Review. Udall Center for Public Policy, University of Arizona (Forthcoming Book). On file at the Water Resources Research Center, University of Arizona, Tucson, Arizona.

Sessions, George.

1990. The Deep Ecology Movement: A Review. Environmental Review Spring:105125.

Shands, William E., Anne Black, and Jim Giltmier.

1993. From New Perspectives to Ecosystem Management: A Report of an Assessment of New Perspectives. Milford, Pennsylvania: The Pinchot Institute for Conservation.

Shannon, Margaret A.

1993. Community Governance: An Enduring Institution of Democracy. In Multiple

Use and Sustained Yield: Changing Philosophies for Federal Land Management.Washington D.C.: U.S. Government Printing Office, pp.219-246.

Sirmon, J., W.E. Shands, and C. Liggett.

1993. Communities of Interests and Open Decision-Making. Journal of Forestry, 91 7:17-21.

Society of American Foresters.

1992. Sustaining Long-Term Forest Health and Productivity. Report of a Task Force of the Society of American Foresters. Bethesda, Maryland: Society of American Foresters.

Stanley, Manfred.

1990. The Rhetoric of the Commons: Forum Discourse in Politics and Society. In The Rhetorical Turn. H.W. Simmons, editor. Chicago: University of Chicago Press,p.238-258.

Steffen, Lloyd H.

1992. In Defense of Dominion. Environmental Ethics 14: 63-80.

Stegner, Wallace.

1987. The American West as Living Space. Ann Arbor: The University of Michigan Press.

Stillman, Peter.

1974. Ecological Problems, Political Theory, and Public Policy. Environmental

Politics.Stuart Nagel editor. New York: Praeger Publishers, pp.49-60.

Stone, Deborah.

1988. Policy Paradox and Political Reason. U.S.A: Harper Collins Publishers.

Straus, Michael W.

1946. The Colorado River -- A Natural Menace Becomes a Natural Resource.Washington, D.C.: United States Department of the Interior.

Thomas, R.L., J.R. Vallentyne, K. Ogilvie, and J.D. Kingham.

1988. The Ecosystems Approach: A Strategy for the Management of Renewable

Resources in the Great Lakes Basin. In Perspectives on Ecosystem Management for 
the Great Lakes: A Reader. Lynton K. Caldwell, editor. SUNY Series in Environmental Public Policy. Albany: State University of New York Press, pp.31-57. Tribe, Lawrence.

1973. The Limits of Instrumental Rationality. Southern California Law Review 46: 617-70.

U.S. Department of the Interior - Bureau of Land Management.

1993. Grazing Administration Regulations. Proposed Rule. Federal Register, August $13,1993$.

Vallentyne, J., and A. Beeton.

1988. The "Ecosystem" Approach to Managing Human Uses and Abuses of Natural Resources in the Great Lakes Basin. Environmental Conservation 15:58-62.

Wallace, Mary G., Hanna Cortner, Margaret A. Moote and Sabrina Burke.

1996. The Role of Social Science in Ecosystem Management: Addressing Issues of Institutional Change and Policy Paradox. Presented at the Sixth International Symposium on Society and Natural Resources, State College Park, Pennsylvania, May 21, 1996. On file at the Water Resources Research Center, University of Arizona, Tucson, Arizona.

Weber, Max.

1968. Economy and Society. New York: Bendminster Press.

Wexler, Philip. editor.

1991. Critical Theory Now. London: The Falmer Press.

White, Lynn.

1967. The Historical Roots of our Ecological Crisis. Science 155:1203-1207.

Whitebrook, Joel.

1979. The Problem of Nature in Habermas. Telos 4040:41-69.

Wilkinson, Charles.

1992. Crossing the Next Meridian: Land, Water, and the Future of the West. Covelo, California: Island Press.

Wondolleck, Julia, and Steven Yaffee.

1994. Building Bridges Across Agency Boundaries: In Search of Excellence in the

U.S.Forest Service. Ann Arbor: School of Natural Resources and the Environment.

Worster, Donald.

1992. Under Western Skies: Nature and History in the American West. New York: Oxford University Press.

Wuthnow, Robert.

1992. Rediscovering the Sacred: Perspectives on Religion in Contemporary Society.Michigan: William B. Eerdmans.

\section{Abstract}

Federal agencies, scientists, and others are increasingly calling for ecosystem management as a new approach to resource management. This approach represents a change in philosophy for resource management that will require changes in how we view nature, science and politics. This paper draws upon critical theory to examine this shift in philosophy. The paper focuses on the influence of Enlightenment thought on U.S. Western resource policy and examines four dimensions including the relationship between humans and nature; the concept of rationality; the nature of science; and social relations among humans. Alternative theoretical principles suggested by ecosystem management are 
discussed. Examples of natural resource management projects that reflect ecosystem management in practice are also presented.

Keywords: natural resource policy, political thory, ecosystem management, U.S. west land management, critical theory, enlightenment thought.

\section{Résumé}

Les Services du gouvernement fédéral, les scientifiques et d'autres appellent de plus en plus pour l'aménagement de l'écosystème comme une approche nouvelle à l'aménagement des ressources. Cette approche représente un changement de philosophie de l'aménagement des ressources qui exigera une nouvelle manière d'envisager la nature, la science et la politique. L'article s'inspire de la théorie critique afin d'examiner cette transformation philosophique. Il se concentre sur l'influence de la pensée du siècle des lumières sur la politique de ressources de l'ouest des Etats-Unis d'Amérique et examine quatre dimensions à savoir le rapport entre les humains et la nature; le concept de rationalité; la nature de la science; et les relations sociales entre les humains. Les principes alternatives théoriques suggérés par l'aménagement des écosystèmes sont discutés. Des exemples de projets d'aménagement des ressources naturelles qui réfléchissent sur la pratique de l'aménagement de l'écosystème sont aussi examinés.

Les Mots-clés: la politique de gestion des ressources naturelles, la théorie politique, l'aménagement de l'écosystème, l'aménagement des terres de l'ouest des Etats-Unis d'Amérique, la théorie critique, la pensée du siècle des lumières.

\section{Resumen}

Agencias federales, científicos y otros han incrementado el llamado por la administración del ecosistema como una nueva perspectiva para el manejo de recursos. Esta perspectiva representa un cambio en la filosofía para manejar recursos que requerirá cambios en como percibimos a la naturaleza, la ciencia, y la política. Este papel utiliza la teoría crítica para examinar el cambio en filosofía. Enfoca en la influencia del Pensamiento Ilustrativo en las políticas del Oeste y de los Estados Unidos, y examina cuatro dimensiones incluyendo la relación entre humanos y la naturaleza, el concepto de la racionalidad, la esencia de la ciencia, y las relaciones sociales entre humanos, ciencia, y las relaciones sociales entre humanos. Principios teoréticos alternativos que son sugeridos por la práctica de administrar el ecosistema serán presentados. Ejemplos del manejo de los recursos naturales que vienen por medio de varios naturales que vienen por medio de varios proyectos serán presentados.

Palabras Claves: Política de los recursos naturales, teoría política, administración del ecosistema, Manejo de la tierra en el oeste de los Estados Unidos, teoría crítica, Pensamiento Ilustrativo. 